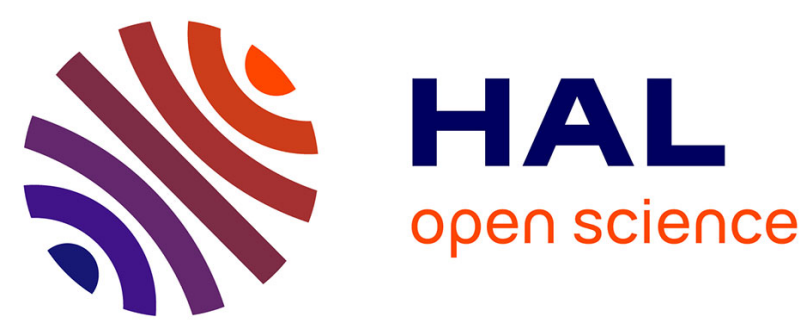

\title{
Comparison of several biomarkers (MMP-2, MMP-9, the MMP-9 inhibitor TIMP-1, CTX-II, calprotectin, and COMP) in the synovial fluid and serum of patients with and without septic arthritis
}

\author{
Marion Couderc, Caroline Peyrode, Bruno Pereira, Elisabeth Miot-Noirault, \\ Sylvain Mathieu, Martin Soubrier, Jean-Jacques Dubost
}

\section{To cite this version:}

Marion Couderc, Caroline Peyrode, Bruno Pereira, Elisabeth Miot-Noirault, Sylvain Mathieu, et al.. Comparison of several biomarkers (MMP-2, MMP-9, the MMP-9 inhibitor TIMP-1, CTX-II, calprotectin, and COMP) in the synovial fluid and serum of patients with and without septic arthritis. Joint Bone Spine, 2018, 10.1016/j.jbspin.2018.04.008 hal-01925157

\author{
HAL Id: hal-01925157 \\ https://hal.science/hal-01925157
}

Submitted on 27 Nov 2019

HAL is a multi-disciplinary open access archive for the deposit and dissemination of scientific research documents, whether they are published or not. The documents may come from teaching and research institutions in France or abroad, or from public or private research centers.
L'archive ouverte pluridisciplinaire HAL, est destinée au dépôt et à la diffusion de documents scientifiques de niveau recherche, publiés ou non, émanant des établissements d'enseignement et de recherche français ou étrangers, des laboratoires publics ou privés. 
Comparison of several biomarkers (MMP-2, MMP-9, the MMP-9 inhibitor TIMP-1, CTX-II, calprotectin, and COMP) in the synovial fluid and serum of patients with and without septic arthritis

Marion Couderc ${ }^{1,2}$, Caroline Peyrode ${ }^{2}$, Bruno Pereira ${ }^{3}$, Elisabeth Miot-Noirault ${ }^{2}$, Sylvain Mathieu ${ }^{1}$, Martin Soubrier ${ }^{1}$, Jean-Jacques Dubost ${ }^{1}$.

${ }^{1}$ Rheumatology department, Clermont-Ferrand University Hospital, France

${ }^{2}$ UMR 1240 Inserm/UCA, IMOST, Clermont-Ferrand, France

${ }^{3}$ Biostatistics unit, DRCl, Clermont-Ferrand University Hospital, France

\section{Corresponding author:}

Dr. Marion Couderc

Rheumatology department

Clermont-Ferrand University Hospital

Place Henri Dunant,

63000 Clermont-Ferrand, France

Email: $\underline{\text { mcouderc@chu-clermontferrand.fr }}$

Word count: 470

Disclosure statement: The authors declare that they have no financial or any other conflicts of interest in relation to this manuscript. 
It is critical to diagnosis septic arthritis (SA) in a timely fashion in order to reduce the risk of irreversible cartilage damage, which has important functional sequelae [1,2]. However, direct Gram stain of synovial fluid is positive in only $25 \%$ to $50 \%$ of SA cases, and the bacteriological results remain negative in approximately $20 \%$ of SA cases [3]. Therefore, readily available and specific biomarkers are needed to help clinicians to decide for hospitalization and antibiotic treatment. This study assessed whether the following serum and synovial biomarkers could distinguish between patients with SA versus non-SA: metalloproteinase MMP-2, MMP-9, tissue inhibitor of MMP (TIMP-1), cartilage oligomeric matrix protein (COMP), C-terminal telopeptide of type II collagen (CTX-II), and calprotectin (CALP).

Serum samples and aspirated synovial fluid samples were prospectively collected from 21 patients with SA. SA was defined as the identification of microorganisms from synovial fluid or blood cultures: Staphylococcus aureus, $n=13$; Streptococcus, $n=4$; Enterobacteria, $n=3$; and coagulase-negative Staphylococcus, $n=1$. We also collected samples from 18 patients with a suspicion of SA who had acutely swollen joints due to other causes: chondrocalcinosis, $n=9$; gout, $n=2$; rheumatoid arthritis, $n=2$; spondyloarthritis, $n=1$; osteoarthritis, $n=3$; and hemarthrosis, $n=1$. TIMP-1, MMP-2, MMP-9, CTX-II, CALP, and COMP levels were measured in synovial fluid and serum using commercial enzyme-linked immunosorbent assay (ELISA) kits and compared between the groups.

The characteristics of the study population are shown in Table 1. Univariate analysis showed that the following were significantly higher in the SA group versus the non-SA group (Table 2$)$ : serum TIMP-1 $(p<0.01)$, synovial MMP-9 $(p<0.01)$; serum $(p<0.05)$ and synovial CTX-II $(p<0.01)$; and serum $(p<0.05)$ and synovial CALP $(p<0.05)$. The AUCs for diagnosing SA based on synovial MMP-9, serum TIMP-1, synovial CTX-II, and serum and synovial CALP were $0.84,0.79,0.81,0.7$, and 0.72 , respectively. When serum TIMP-1 and synovial CTX-II were combined and thresholds of $286.5 \mathrm{ng} / \mathrm{mL}$ and $873 \mathrm{ng} / \mathrm{mL}$ were used, respectively, the sensitivity was $75 \%$ and the specificity was $94 \%$ for diagnosing SA. This combination correctly classified patients in $86 \%$ of cases. Synovial MMP-9 substantially correlated with C-reactive protein $(r=0.61)$, whole blood white blood cell count [WBC] $(r=0.46)$, synovial $W B C(r=0.66)$ and the polymorphonuclear cell percentage $(r=0.51)$ in synovial fluid. Serum TIMP-1 and synovial CTX-II did not correlate with each other ( $r=0.1$ ) or with CRP ( $r=0.4$ and $r=0.25$, respectively) or synovial WBC ( $r=-0.04$ and $r=0.27$, respectively). 
Table 1: Clinical characteristics and laboratory data of the study population

\begin{tabular}{|c|c|c|c|}
\hline & & & \multirow{3}{*}{ p-value } \\
\hline & SA group & Non-SA group & \\
\hline & $\mathrm{n}=21$ & $\mathrm{n}=18$ & \\
\hline Age, years, mean $\pm S D$ & $64.5 \pm 21.1$ & $64.8 \pm 12.6$ & 0.96 \\
\hline $\begin{array}{l}\text { Male gender, } \mathrm{n} \\
(\%)\end{array}$ & $12(57.1)$ & $8(44.4)$ & 0.43 \\
\hline Diabetes, n (\%) & $5(23.8)$ & $2(11.1)$ & 0.42 \\
\hline \multirow{4}{*}{$\begin{array}{c}\text { Knee, n (\%) } \\
\text { Shoulder, n (\%) } \\
\text { Hip, n (\%) } \\
\text { Elbow, n (\%) }\end{array}$} & $14(66.7)$ & $15(83.3)$ & \multirow{4}{*}{0.24} \\
\hline & $4(19)$ & $2(11.1)$ & \\
\hline & $3(14.3)$ & $0(0)$ & \\
\hline & $0(0)$ & $1(5.6)$ & \\
\hline Max. temperature, ${ }^{\circ} \mathrm{C}$, mean $\pm \mathrm{SD}$ & $38.3 \pm 0.7$ & $38.1 \pm 0.7$ & 0.38 \\
\hline Chills, n (\%) & $7 / 18(38.9)$ & $4 / 18(22.2)$ & 0.28 \\
\hline $\begin{array}{l}\text { Presence of an entry site for } \\
\text { infection, } n(\%)\end{array}$ & $15 / 20(75)$ & $8 / 18(44)$ & 0.054 \\
\hline \multicolumn{4}{|l|}{ Serum: } \\
\hline 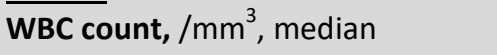 & $10770[8250-13260]$ & $8230[4900-11400]$ & $0.03^{*}$ \\
\hline CRP, mg/L, median [Q1-Q3] & $209[122-256]$ & $90[35-184]$ & 0.06 \\
\hline Radiological signs of SA, $n(\%)$ & $7 / 18(38.9)$ & $1 / 17(5.9)$ & 0.04 \\
\hline \multicolumn{4}{|l|}{ Synovial fluid: } \\
\hline Turbid, n (\%) & $13 / 19(68.4)$ & $2 / 17(11.8)$ & $0.001^{*}$ \\
\hline WBC count $>50000 / \mathrm{mm}^{3}, \mathrm{n}(\%)$ & $7 / 16(43.7)$ & $3 / 18(16.7)$ & 0.09 \\
\hline PMN, \%, median [Q1-Q3] & 90 [89-93] & $89[84-90]$ & 0.17 \\
\hline
\end{tabular}

Values are expressed as mean \pm standard deviation (SD) or median [Q1-Q3] for continuous variables and $n$ (\%) for categorical variables. ${ }^{*}<0.05$

SA: septic arthritis, CRP: C-reactive protein, WBC: white blood cell, PMN: polymorphonuclear cell 
*: p-value < 0.05, Mean + SD: mean and standard deviation, AUC: area under the curve, Cl: confidence interval, MMP: metalloproteinase, TIMP: metalloproteinase inhibitor, CTX: C-terminal telopeptide of collagen, COMP: cartilage oligomeric matrix protein.

\begin{tabular}{|c|c|c|c|}
\hline Marker level & Septic arthritis ( $n=21)$ & $\frac{\text { Non-septic arthritis }}{(\mathrm{n}=18)}$ & p-value \\
\hline $\mathrm{MMP}-2$ serum, mean $\pm \mathrm{SD}, \mathrm{ng} / \mathrm{mL}$ & $90 \pm 35.6$ & $77.1 \pm 26.5$ & 0.2 \\
\hline $\begin{array}{l}\text { MMP-2 synovial fluid, mean } \pm \mathrm{SD} \text {, } \\
\mathrm{ng} / \mathrm{mL}\end{array}$ & $248.5 \pm 131$ & $241.8 \pm 109.4$ & 0.7 \\
\hline MMP-9 serum, mean \pm SD, $\mathrm{ng} / \mathrm{mL}$ & $2856 \pm 1997$ & $2190 \pm 1920$ & 0.2 \\
\hline $\begin{array}{l}\text { MMP-9 synovial fluid, mean } \pm \text { SD, } \\
\mu \mathrm{g} / \mathrm{L}\end{array}$ & $49.6 \pm 26.3$ & $20.7 \pm 16.5$ & $0.002^{*}$ \\
\hline TIMP-1 serum, mean \pm SD, $\mathrm{ng} / \mathrm{mL}$ & $320.6 \pm 169$ & $170.8 \pm 69.2$ & $0.003^{*}$ \\
\hline $\begin{array}{l}\text { TIMP-1 synovial fluid, mean } \pm \text { SD, } \\
\mathrm{ng} / \mathrm{mL}\end{array}$ & $947 \pm 315$ & $948.1 \pm 377.1$ & 0.7 \\
\hline CTX-II serum, mean $\pm \mathrm{SD}, \mathrm{ng} / \mathrm{mL}$ & $1036.9 \pm 549.2$ & $653.5 \pm 268$ & $0.03 *$ \\
\hline $\begin{array}{l}\text { CTX-II synovial fluid, mean } \pm \text { SD, } \\
\mathrm{ng} / \mathrm{mL}\end{array}$ & $1069.9 \pm 540.3$ & $673.5 \pm 335.5$ & $0.004^{*}$ \\
\hline COMP serum, mean $\pm \mathrm{SD}, \mathrm{ng} / \mathrm{mL}$ & $304.4 \pm 216.1$ & $271.4 \pm 157.3$ & 0.8 \\
\hline $\begin{array}{l}\text { COMP synovial fluid, mean } \pm \mathrm{SD} \text {, } \\
\mathrm{ng} / \mathrm{mL}\end{array}$ & $4210 \pm 3523$ & $6098 \pm 4161$ & 0.2 \\
\hline CALP serum, mean $\pm S D, m g / m L$ & $2.5 \pm 1.4$ & $1.6 \pm 1$ & $0.04 *$ \\
\hline $\begin{array}{l}\text { CALP synovial fluid, mean } \pm \mathrm{SD} \text {, } \\
\mu \mathrm{g} / \mathrm{mL}\end{array}$ & $1270.9 \pm 605.3$ & $798.1 \pm 604.8$ & $0.03 *$ \\
\hline
\end{tabular}

To our knowledge, this is the first study to assess the performance of numerous potentially useful markers in synovial fluid and serum samples of patients with suspected SA. Synovial CTX-II is especially interesting because it appears to add new information regarding cartilage degradation, along with inflammatory host response biomarkers like synovial WBC or CRP.

This preliminary study demonstrates that two biomarkers, serum TIMP-1 and synovial CTX-II, merit further assessment in terms of their diagnostic and prognostic value in a larger cohort of patients with suspected SA. 


\section{References}

[1] Dubost JJ, Soubrier M, Sauvezie B. Pyogenic arthritis in adults. Jt Bone Spine Rev Rhum 2000;67:11-21.

[2] Margaretten ME, Kohlwes J, Moore D, Bent S. Does this adult patient have septic arthritis? JAMA 2007;297:1478-88.

[3] Eberst-Ledoux J, Tournadre A, Mathieu S, Mrozek N, Soubrier M, Dubost J-J. Septic arthritis with negative bacteriological findings in adult native joints: a retrospective study of 74 cases. Jt Bone Spine Rev Rhum 2012;79:156-9. 